\title{
IMMUNIZATION OF THE PERITONEUM*
}

\author{
Frederick A. Coller, m.D. \\ Professor of Surgery, University of Michigan \\ Medical School
}

AND

Instructor in Surgery, University of Michigan
Medical School

ANN ARBOR MICHIGAN

$\mathrm{S}$ INCE the advent of major abdominal surgery the problem of postoperative peritonitis has been an extremely important one and still presents itself as a challenge to the surgeon from the standpoint of both prevention and cure. During the past fifty years there has been a large amount of work done on the production of peritonitis in various experimental animals, and attempts have been made to correlate the findings in animals with the peritonitis which occurs in the human being. Such attempts have been far from satisfactory and there is still need for more carefully controlled laboratory and clinical investigation in the field.

The early workers on experimental peritonitis found it difficult to produce a true fibrinopurulent peritonitis by the intraperitoneal injection of bacteria. They could earily produce a bacteremia, or, with more virulent organisms, could get a lethal effect, but not a peritoneal exudate. It therefore occurred to them that peritonitis per se was probably not the cause of death, but was in reality a protective mechanism, and that the animals, paradoxically enough, died from a want of inflammatóry reaction rather than as a result of it. Herrman, in 1927, at the Mayo Clinic, showed that in order to produce a peritoneal exudate in the rabbit it was first necessary to build up an immunity before injecting the infecting material. This was successfully carried out by using repeated small intraperitoneal doses of a vaccine prepared from the colon bacillus and Streptococcus viridans. At autopsy the animals showed a true frbrinopurulent peritonitis, but control animals which received no such immunizing vaccine died promptly with no visible evidence of peritonitis. Today, this concept regarding the production of peritonitis is generally accepted, and comes to our attention every time we perform an abdominal operation. We know that the degree of resistance of the peritoneum will vary with the extent to which the peritoneum has been previously immunized. In cases of regressing acute cholecystitis, in which pus is spilled into the peritoneal cavity at operation, there is no grave danger from a subsequent severe peritonitis. This resistance of the peritoneum to a limited amount of infection is probably not due to any "natural" or "inherent" immune quality, but is more likely the result of an excellent blood and lymphatic supply.

Attempts to immunize the peritoneum by the intraperitoneal injection of vaccines and various foreign substances are by no means new. As early as I887 Pawlowsky used croton oil to produce peritonitis in experimental animals. The problem was more actively studied by Issaef in 1894 when he introduced the idea of vaccination to prevent postoperative peritonitis. Pierralini, in 1897 , found that a leucocytic exudate could be produced by the intraperitoneal injection of sodium chloride and other inert substances. In the same year Garniér demonstrated that bacteria were rapidly destroyed in the presence of such a leucocytic exudate in the peritoneal cavity, and his researches revealed a new concept regarding the mechanism of protection from an otherwise fatal peritonitis, namely phagocytosis. In 1902, Solieri, working on the theory that "immunity" was a result of phagocytosis, produced a peritoneal leucocytic exudate, and found that animals 
with such an inflammatory reaction of the peritoneum survived a colon bacillus peritonitis.

The problem of peritoneal immunization was reopened in this country by Steinberg and Goldblatt in 1926, and since then they, working together and individually, have done a large amount of research on this phase of peritonitis. Their earlier experiments showed that intraperitoneal immunization by living and heat-killed colon bacilli produced an immunity to subsequent colon bacillus and fecal peritonitis. Later, in a series of experiments in which they studied the cause of death in peritonitis, they presented convincing evidence concerning the rate of passage of bacteria from the peritoneal cavity into the Iymph and blood streams. Working with dogs, they found that when colon bacilli in saline suspension were injected intraperitoneally they were rapidly absorbed into the blood and Iymph, and that such animals practically always survived. However, when equal doses of the colon bacillus were suspended in I per cent gum tragacanth, the animals did not get a bacteremia, but invariably diet. The hypothesis was therefore formulated that toxic products of the bacteria were formed in quantity only when they were retained within the peritoneal cavity, and that such toxic products were the cause of the death of the animal.

Concurrently, David and Sparks, in 1927, threw further light on the mechanism of absorption of bacteria, and helped to establish the belief that peritonitis serves a protective function. They showed in animals that when colon bacilli were injected intraperitoneally they passed readily into the blood and Iymph. When, however, a plastic peritonitis was first produced by injection of a turpentine emulsion, organisms subsequently injected intraperitoneally could not be recovered from the blood stream or thoracic duct.

Peritoneal "immunity," so-called, is probably not a true immunity but a local form of protection which manifests itself as a reaction of the peritoneum to trauma and infection. In this connection, most students of peritonitis feel that phagocytosis plays an important protective rôle. There is, however, no uniformity of opinion regarding the relative protective functions of the polymorphonuclear leucocytes and the large mononuclear cells or histiocytes.

Since his earliest studies, Steinberg has contended that the protection secured from intraperitoneal vaccination is a result of phagocytosis of otherwise harmful bactcria. He regards the polymorphonuclear leucocyte as the important cell serving in this capacity, and has designated this type of protection "hyperleucocytic pre-immunity." He feels that the histiocyte is a "scavenger" cell which appears relatively late in peritonitis, where it can be demonstrated to engulf degenerated polymorphonuclears in this stage of the disease. He has emphasized the point that the polymorphonuclear cells act early in carrying out their phagocytic function.

At the Mayo Clinic the opinion has prevailed among the various workers that the histiocyte is probably the most important cell concerned with phagocytosis. Hermann early expressed this belief in his work on rabbits and since then it has been supported by other investigators. In I933, an interesting study on the peritoneal fluid of man was carried out by Rixford. He had an opportunity to study the peritoneal fluid in patients at operation which had previously received intraperitoneal vaccine, and to compare these findings with a control group of patients which had received no vaccine. Specimens were taken with a glass pipette just after the peritoneal cavity was opened. In unvaccinated cases, the total white cell count averaged from $\mathrm{I}, 900$ to 2,600 per c. $\mathrm{mm}$. of fluid. There were practically no neutrophiles, very few eosinophiles and basophiles, but many Iymphocytes and histiocytes (45 per cent). In patients who had been vaccinated 24 to I 44 hours prior to operation, specimens of peritoneal fluid were also examined. There was considerable variation in the findings, but it was apparent that there was an early 
increase in polymorphonuclear cells and a delayed but nevertheless marked increase in histiocytes.

The cell counts of the total peritoneal fluid have been carefully made by Seeley, Higgins, and Mann. Working with rats, they used various substances to evoke a peritoneal reaction, and then removed and weighed all the fluid present, in addition to making differential cell counts. Following injections of amniotic fluid concentrate, Bargen's vaccine (prepared from colon bacilli and nonhemolytic streptococci) and sodium ricinoleate, they found that with all materials there was an early and rapid rise of polymorphonuclears, reaching a maximum in three to six hours. Histiocytes appeared much later, but, were the preponderant cells after six or seven days. The response of both cells was greater in those animals receiving sodium ricinoleate.

In 1937, Corwin, working with rabbits, reported that the cellular responses to Bargen's vaccine and sodium ricinoleate were nearly identical qualitatively. The intervals for maximal cellular reactions varied, however. With Bargen's vaccine, the cell count of the peritoneal fluid was greatest at twelve hours, with I per cent sodium ricinoleate at twenty-four hours, and with 2 per cent sodium ricinoleate at forty-eight hours. The differential count again showed that polymorphonuclears appeared early, being in greatest abundance in six to twelve hours, while the histiocytes were maximal in one to three days.

It is apparent from the above studies that variation in opinion regarding the relative phagocytic properties of the neutrophiles and histiocytes is due in part to the use of different species of animals by various workers. The type of material used to evoke a reaction, the dosage employed, and the time intervals for examination of the fluid are also inconstant factors which must be evaluated in arriving at a definite conclusion.

In order to prove or disprove the value of any of the numerous agents that have been used to immunize the peritoneum, it would be necessary to use such an agent in a very large series of patients having major abdominal operations, and at the same time have an equally large number of similar cases as a control group. As yet no such investigation has been reported. However, during the past ten years there are three immunizing agents which have been' employed more extensively than numerous other substances. These are (I) the vaccine developed by Steinberg and Goldblatt, (2) the vaccine prepared by Bargen, and (3) the amniotic fluid preparations originally suggested by Johnson.

Steinberg and Goldblatt, working on the idea that a marked leucocytic reaction in the peritoneal cavity could be more easily produced by some agent which prevented a rapid absorption of bacteria, developed a protective emulsion which they have called coli-bactragen. This preparation has since been modifred by Steinberg, and his formula for the more recent preparation is as follows:

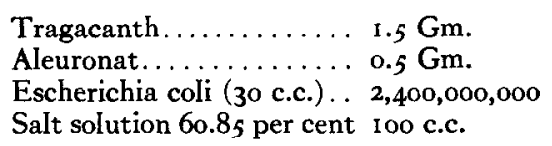

Today there is ample evidence that this emulsion will protect the experimental animal from certain types of subsequently induced peritonitis. Steinberg has succeeded in demonstrating protection against living colon bacilli, streptococcus fecalis, B. pyocyaneus, and clostridia welchi, in both pure and mixed cultures.

In the collected series of 400 patients receiving coli-bactragen which were reported by Goldblatt in 1934, eight postoperative deaths were recorded, but only three of these could be attributed to peritonitis. In the majority of patients who were operated upon by various surgeons, a resection of a part of the large bowel was performed. The preparation employed was injected intraperitoneally about forty-eight hours before Iaparotomy was performed and was frequently accompanied by a rather severe general reaction. The patient 
was occasionally so sick from the vaccination that operation was necessarily postponed. The series was too small, however, to permit any conclusions regarding the efficacy of the vaccine. The more recent preparation of coli-bactragen is an improvement over the former one, not only in that it produces a less severe general reaction, but has the additional advantage of achieving its maximum protection within a few hours, thereby permitting its being introduced at the time of operation. Steinberg has found that the period of maximum protection is shortened by using formaldehyde rather than heat to kill the colon bacilli.

In 1935, Potter and Coller reported their results on a series of patients who were given coli-bactragen prior to operation. In seventy-nine patients, most of whom required major operations upon the colon, there were eleven deaths, but in only one could the fatal outcome be definitely attributed to peritonitis. They noted that the peritoneal reaction varied from a mild hyperemia to an abundant exudate resembling that of a fibrinopurulent peritonitis. Although the series of cases was too small to permit definite conclusions, they were of the opinion that the value of the vaccine was questionable except in cases of gross fecal contamination. In 1936, Coller and Ransom reported the use of colibactragen in seventy-nine cases which had a combined abdominoperineal resection for carcinoma of the rectum and rectosigmoid. There were twelve deaths, but in none could death be proved to be the results of peritonitis. In the same year Steinberg reported 391 cases in which coli-bactragen was used preoperatively or at the time of operation, with none developing postoperative peritonitis.

In 1928, at the Mayo Clinic, based on experimental work done by Herrmann, Bargen developed a vaccine prepared from streptococci and colon bacilli. The vaccine was given three days before operation involving intestinal resections. In 1935 Dixon and Bargen reported having used the vaccine in $I, 500$ such cases, with a reduction of 66 per cent in the mortality rate from postoperative peritonitis. The reaction from the vaccine usually consisted in a temperature elevation to $102^{\circ}$ or $103^{\circ} \mathrm{F}$. which receded in a gyrate fashion and returned to normal twenty-four to thirtysix hours after vaccination. In 1930, Rankin, in a review of 527 surgical lesions of the large intestine and rectum in which peritoneal vaccination was used preoperatively, reported a mortality rate of 12.3 per cent by patient and 8.6 per cent by operation. In 1933 , he began a new series of operations upon organic lesions of the colon and rectum in which the vaccine was not used. In 200 consecutive operations upon I30 patients he reported a mortality rate of 5.5 per cent by operation and 8.4 per cent by operation. Rankin has attributed the decline in mortality to better preoperative preparation rather than to vaccination.

Johnson, in 1922, first conceived the idea of using amniotic fluid to prevent postoperative adhesions, and since then he has used it as an agent to assist in the processes of peritoneal defense and repair. While the use of a substance which allegedly prevents adhesion formation but at the same time protects against peritonitis seems paradoxical, Johnson explains that the action of amniotic fluid on the peritoneum is to produced a protective layer of fibrin on the serous surfaces and a moderate local leucocytosis, which is followed later by a complete resolution of the fibrinous deposit. The amniotic fluid used is obtained from cows two to five months pregnant. It is sterilized by the Berkfeld filter method. Johnson is of the opinion that amniotic fluid provokes a peritoneal reaction which is entirely within the limits of safety, gives an early response, and produces only a minimum physiologic disturbance. He describes the peritoneal reaction as a "defense response characterized by hyperemia, marked subserous edema, increase in peritoneal fluid, and the formation of a pink-tinged frbrinous exudate. There is an increased white cell count 
which rises rapidly for about twelve hours, at which time the differential count shows a marked preponderance of polymorphonuclear leucocytes. Having reached its peak, the white cell content of the exudate gradually recedes and the neutrophiles are replaced by the histiocytes. The total white cell count finally becomes preponderantly histiocytic." He states that when the exudate is removed from the peritoneal cavity it quickly forms a fibrin clot. By contrast he points out that following the intraperitoneal injection of vaccines there is a very severe reaction characterized by a profuse hemorrhagic exudate which does not clot upon removal and exposure to air.

Johnson's work has been collaborated in by Warren, Trusler, Young and Marks, Kimpton and others. In 1934, Young and Marks reported on the use of amniotic fluid concentrate in forty-nine cases which involved, for the most part, operations on the large intestine. There were three deaths, but in only one instance could death be attributed to postoperative peritonitis. In a series of forty-six similar cases in which amniotic fluid was not used preoperatively they reported eight deaths, or a mortality of 17.3 per cent, from postoperative peritonitis. In the latter group, when they included only the cases in which the bowel was resected, there was a mortality of $3^{8}$ per cent. In 1936, Gepfert reported on the use of concentrated fractions of bovine amniotic fluid (amfetin, Lilly). He was of the opinion that patients receiving amniotic fluid had a smoother postoperative course than did a similar group of control patients.

Further studies in nonspecific peritoneal immunization were reported by Morton in 193 I. He used various substances to vaccinate the peritoneum, particularly dextrose broth, heated streptococcus filtrate, various solutions of glucose, and sodium chloride. Using rabbits, he found that he was able to establish a certain degree of protection in most of the animals at the end of sixty hours, and, at the end of several days, "immunity was proved in Ioo per cent."

The use of bacteriophage has given a variety of results, both experimentally and clinically. Rice gave a negative report of his work on local immunization by the use of bacteriophage in 1933. Immunization of the peritoneum of dogs was attempted by injecting intraperitoneally a mixture of staphylococcus, streptococcus, and B. coli bacteriophage filtrates. The animals were given bacteriophage before or at the time of operation, which consisted in tying off the cecum in order to produce peritonitis. Under the conditions of the experiments, it was found that the bacteriophage failed to immunize the peritoneum. Moreover, it seemed to inhibit the formation of plastic exudates when used before or during operation. Rice expressed the opinion, however, on the basis of previous clinical experience, that bacteriophage was of value in treating abscesses which were well walled off.

Jern, Harvey, and Meleney, working with mice, reported in 1932 on their use of bacteriophage to protect against colon bacillus peritonitis. They found that they were able to protect the animals against such an infection, even when they used doses twenty-five times the lethal dose for normal controls. The phage was effective when used intraperitoneally before, during, or even several hours after the injection of the colon bacilli.

It is apparent that numerous difficulties are encountered when one studies the problems connected with the use of bacteriophage. There is a marked difference in the susceptibility of various strains of the colon bacillus to lysis by bacteriophages. Against the streptococcus, which is probably the second most common, and one of the most virulent, organisms causing peritonitis, there are few active bacteriophages. Moreover, the behavior of a bacteriophage is unpredictable; it may fail to cause lysis of a particular strain of organisms but at the same time be effective in causing lysis of unrelated bacteria. At present it cannot be 
said that there is sufficient clinical evidence to prove the value of any of the single or combined bacteriophages, but there are sporadic reports of success in treating a relatively small number of peritonitis.

Filtrates have been used several years to immunize the peritoneum, but up to the present time there is very little evidence, either experimental or clinical, to indicate that they are of value. Further work will be necessary to elucidate regarding their present contradictory status.

In spite of the fact that there has been a large amount of thorough experimental work on the immunization of the peritoneum, there still remains a wide gap to be filled if our experimental knowledge is to be applied to the human being. Such factors as the species of laboratory animal used, type and dose of immunizing substance employed, and the time and mode of its administration, make it difficult to compare the findings of one investigator with those of another. It is logical to assume that the peritoneum of one animal will not react in the same manner as the peritoneum of another, and that they will all differ in some respects from that of the human. Any absolute proof regarding the value of immunization in the human would necessarily depend upon results obtained in a very large control group of similar cases in which no immunizing agent was used. As yet no adequate control series has becn reported.

From a clinical viewpoint, the newer concept of the protective value of the exudate in peritonitis has a practical value. In operations done upon patients with peritonitis it would seem harmful to carry out manipulations designed to wipe or wash away exudate that is part of a protective mechanism against the infection. If free exudate is removed it must be done in the gentlest fashion by careful aspiration.

\section{CONCLUSIONS}

We can see no reason for the routine use of any of the substances suggested to increase the immunity of the peritoneum.
If patients are properly prepared for operation, and if the operation is carried out with careful meticulous technique, peritonitis rarely supervenes. We do feel that the use of some substance that will produce rapid local leucocytic response is of value in those instances in which, because of accident of operation or disease, the large bowel is opened. Our own experience in these circumstances has been most extensive and most satisfactory with colibactragen (Steinberg). We feel that it has a distinct value when used in the contaminated stage, and that it has little or no value once the infected stage is established. Postoperative peritonitis in clean cases is usually due to errors of operative technique that cannot be corrected by the introduction into the peritoneum of anything except better surgery.

\section{REFERENCES}

i. Buchinder, J. R., Heilman, F. R., and Foster, G. C. Experimental peritonitis II. The effect of hypertonic dextrose solution upon experimental diffuse peritonitis. Surg., Gynec. \&s Obst., 49: 788, 1929.

2. Corwin, W. C. The peritoneal cytologic response: an experimental study. Am. J.M. Sc., 193: 251 (Feb.) 1937 .

3. David, V. C., and Sparks, J. L. The peritoneum as related to peritonitis. Ann. Surg., 88: 672 , 1928.

4. Dixon, C. F., and BARGEN, J. A. Vaccination preceding colonic operations as protection against peritonitis. New York State J. Med., 35: 529, I935.

5. Dixon, C. F., and Rixford, E. L. Cytologic response to peritoneal irritation in man. Am. J. Surg., 25: 504, 1934.

6. GaRnier, M. Recherches sur Ia destruction des microbes dans la cavité péritonéale des cobayes immunisés. Ann. Inst. Pasteur, I 1 : 767, 1897.

7. GEPFERT, J. R. Intraperitoneal use of amniotic fluid to promote smoother postoperative convalescence. Am. J. Surg., 32: 40, 1936.

8. Herrmann, S. F. Experimental peritonitis and peritoneal immunity. Proc. Staff. Meet., Mayo Clin., 3: 21, 1928 .

9. ISSAEF. Untersuchungen über die kunstliche Immunität gegen Cholera. Ztscbr. f. Hyg. u. Infectionskrankb., 16: 287, 1894 .

io. Jern, H. Z., Harvey, H. D., and Meleney, F. L. B. coli bacteriophage in the treatment of B. coli peritonitis in mice. Proc. Soc. Exper. Biol. of Med., 29: 74I, 1932 .

I1. JoHnson, H. L. Observations on the prevention of postoperative peritonitis and abdominal adhesions. Surg., Gynec. of Obst., 45: 612, 1927. 
12. Johnson, H. L. An exposition of the preparation and administration of amniotic fluid concentrate, New England J. Med., 21 2: 557, 1935.

13. Johnson, H. L. Peritoneal immunization. Am. J. Surg., $34: 266,1936$.

I4. Jornson, H. L. Amniotic fluid concentrate as an activator of peritoneal immunity. Surg., Gynec. of Obst., 62: 171, 1936.

15. Kennedy, J. W. Functions of the peritoneum; their effect on the surgical pathology of peritonitis. Pennsylvania $M . J ., 42: 130,1936$.

I6. Kimptom, A. R. Amniotic fluid concentrate: postoperative use to stimulate defense and repair. New England J. Med., 207: 465, 1932.

17. Morton, H. B. Nonspecific peritoneal immunization. Surg., Gynec. Obst., 52: 1093, r931.

i8. Pierallini, G. Sur Ia phagolyse dans Ia cavité péritonéale. Ann. Inst. Pasteur, I897, p. 308.

I9. Rankin, F. W. Resection of the rectum and rectosigmoid by single or graded procedures. Ann. Surg., 104: 628, 1936.

20. Rankin, F. W., and Bargen, J. A. Vaccination against peritonitis in surgery of the colon. Arcb. Surg., 22: 98, 1931.

2i. Rhea, C. E., and Wangensteen, O. H. Comparative efficacy of substances employed in the prevention of intraperitoneal adhesions. Proc. Soc. Exper. Biol. of Med., 31 : 1066, 1934.

22. Rice, T. B. The Iocal immunization of the peritoneum by the use of bacteriophage: a negative report. J. Lab. \& Clin. Med., 5 I : 381, 1933.

23. Rixford, E. L. Bacteriophage in surgery of the colon. Tr. A. S. A., 49: 226, 1931.

24. Rixford, E. L. Cytologic response to vaccine administered intraperitoneally to man. Proc. Staff Meet., Mayo Clin., 8: 586, I 933.

25. Schattenberg, H. S., and Harris, W. H. Comparative study of the rabbit leucocyte count following injection of various antigenic substances. Proc. Soc. Exper. Biol. Med., 29: 265, I93I.

26. Seeley, S. F, Higgins, G. M., and Mann, F. C. Studies on peritonitis: the cytologic response of the peritoneal fluid to certain substances. Proc. Staff Meet., Mayo Clin., ıo: 793, 1935.

27. Solieri, S. ExperimenteIle Untersuchungen über die Veränderungen des Wiederstandes des
Peritoneums gegen die Infection durch Bacterium coli. Beitr. z. Patb. Anat. u.z. allg. Patb., 31: 536, 1902.

28. Steinberg, B. Active immunization methods against acute diffuse peritonitis. Am. J. Clin. Patb., 2: 187, 1932.

29. Steinberg, B. A rapid method of protecting the peritoneum against peritonitis. Arcb. Surg., 24: 308, 1932.

3o. Steinberg, B. An improved method of protecting the peritoneum of dogs against fatal colon bacillus infection. Proc. Soc. Exper. Biol. \& Med., 29: 1018, 1932.

31. Steinberg, B. The experimental background and the clinical application of the Escherichia coli and gum tragacanth mixture in prevention of peritonitis. Am. J. Clin. Patb., 6: 253, 1936.

32. Steingerg, B. Inflammation of serous surfaces. Transfer of living Icucocytes and the effect on acute infectious states. Arch. Patb., 25:785, 1938.

33. Steinberg, B., and Ecker, E. E. The effect of antiserum against the soluble toxic substances of bacillus coli in bacillus coli peritonitis. J. Exper. Med., 43: 443, 1926.

34. Steinberg, B., and Goldblatt, H. Passage of bacteria from the peritoneal cavity into the Iymph and blood. Arcb. Int. Med., 39: 449, 1927.

35. Steinberg, B., and Snyder, D. Immune cellular reactions in experimental acute peritonitis. Arcb. Patb., 8: 419, 1929.

36. Trusler, H. M. Peritonitis: an experimental study of healing in the peritoncum and the therapeutic effect of amniotic fluid concentrate. Arcb. Surg., 22: 983 , I 93 I.

37. voN Mikulicz, J. Versuche über Resistenzvernschrung des Peritoneums gegen Infection, bei Magen-und Darmoperationem. Arcb. f. klin. Cbir., 73: 347, 1904.

38. Warren, $S$. The effect of amniotic fluid on serous surfaces. Arcb. Patb., 6: 860, 1928.

39. Wilkie, D. P. D. The prognostic value of an immediate examination of peritonitis exudates. Internat. Clin., 4: 145, 1912, Series 22.

40. Young, E. L., and Marks, G. A. Preoperative preparation of the peritoneum in surgery of the large intestine. Surg., Gynec. es Obst., 59: 610, 1934. 